Journal of Advanced Research in Fluid Mechanics and Thermal Sciences

\title{
Organic Substances Reduction in Palm Oil Mill Effluent (POME) After Cultivation with Locally Isolated Microalgae
}

\author{
Elvitriana ${ }^{1,2,}{ }^{*}$, Erman Munir $^{1}$, Delvian ${ }^{1}$, Hesti Wahyuningsih ${ }^{1}$ \\ Natural Resources and Environment Management Study Program, University of Sumatera Utara, 20155, Medan, Indonesia \\ Environmental Engineering Department, Faculty of Engineering, University of Serambi Mekkah, 23249, Banda Aceh, Indonesia
}

\section{$\begin{array}{ll}\text { ARTICLE INFO } & \text { ABSTRACT }\end{array}$}

Article history:

Received 8 October 2020

Received in revised form 22 February 2021

Accepted 25 February 2021

Available online 3 March 2021

\begin{abstract}
This work aims to study the ability of locally isolated microalgae to reduce organic substances in Palm Oil Mill Effluent (POME) which was carried out on a laboratory scale. Inoculum with a concentration of $20 \%$ was cultivated into POME media with various concentration of $\mathrm{LP}_{100}$ (without dilution), $\mathrm{LP}_{75}$ (25\% dilution), and $\mathrm{LP}_{50}$ (50\% dilution) using aeration and continuous lighting for 15 days in vessels with a lighting intensity of 1300 lux. Biomass of microalgae were observed daily and analyzed in dry weight by means of spectrophotometry using $624 \mathrm{~nm}$ wavelength to get their growth by determining the content of algae biomass. The reduction of organic substances in POME was observed by measuring the COD, BOD phosphate, ammonium, nitrate, and fatty oil parameters every 3 hours with the standard method. Results show that the growth of microalgae occurred well in POME media at $\mathrm{LP}_{75}$ and $\mathrm{LP}_{50}$ concentrations with inoculum concentration of $20 \%$ under 1300 lux lighting intensity conditions with a continuous 24 -hour lighting and aeration cycle that obtained biomass content of 0.92 and $1.08 \mathrm{~g}-\mathrm{DW} / \mathrm{L}$, respectively. The presence of microalgae in POME at concentration of $\mathrm{LP}_{75}$ for 12 days reduced organic substances and nutrients reaching $80.74 \%$ - 99.70\%. Some parameters that were reduced include BOD $(99.35 \%)$, COD (89.57\%), TSS (89.68\%), Phosphate (97.70\%), Ammonium (95.08\%), Fatty Oil (99.70\%), and Nitrates (80.74\%). This study concludes that locally isolated microalgae have ability to treat POME safely for environment and as a growing medium for microalgae followed by a decrease in organic substances.
\end{abstract}

Keywords:

POME; locally isolated microalgae; green microalgae; biomass

\section{Introduction}

The palm oil industry in Indonesia continues to develop and Indonesia become a developed country that has become the engine of palm oil development in Southeast Asia [1]. The dominance of palm oil in the food processing industry makes it a vegetable oil that is widely produced in the world. Increasing the amount of palm oil production will be followed by an increase in liquid waste generated, that have a negative impact on the environment. Prevention and mitigation of negative impacts from the activities of the palm oil industry continue to be carried out in line with efforts to increase their positive impacts [2]. The palm oil industry wastewater management methods carried

\footnotetext{
* Corresponding author.

E-mail address: elvitriana@serambimekkah.ac.id
}

https://doi.org/10.37934/arfmts.80.2.98105 
out so far need to be developed to obtain more effective methods, so that they get the right strategy in handling them [3]. Bakar et al., introducing a water-mixing burner system that has potential to reduce harmful emissions from sludge palm oil (SPO). Reduction of SPO from treatment ponds, wastewater could further meet Department of Energy (DOE) standards, becoming less harmful to the environment [4]. Islam et al., also developed enzymatic pretreatment of POME for monomers leading to biogas production. They reported that lipase and cellulose enzymes had a significant effect on POME to produce monomers to increase production of biogas under anaerobic digestion [5].

Palm oil industry wastewater comes from condensate, clarification stations, and hydro-cyclone better known as the Palm Oil Mill Effluent (POME). This POME is not toxic, but has high pollution because it contains organic substances with BOD values ranging from $18,000-48,000 \mathrm{mg} / \mathrm{L}$ and COD values ranging from $45,000-65,000 \mathrm{mg} / \mathrm{L}$, while the total nitrogen content in the palm oil industry wastewater ranges from $500-800 \mathrm{mg} / \mathrm{L}$ [6]. This POME also contains a number of suspended and dissolved solids with high concentrations of organic substances, such as cellulose, proteins, fats which are removed without being processed will make deposits that are difficult to decompose, thereby affecting the content of dissolved oxygen.

POME has the potential to supply microalgae nutrients because it contains Carbon, Nitrogen, Phosphate, so that it can reduce the need for nutrients that must be supplied from outside in carrying out photosynthesis. Palm oil industry wastewater with a certain concentration has a CNP ratio, whereas microalgae require large amounts of nutrients with CNP $=56: 9$ : 1 [7]. Utilization of microalgae for processing wastewater has several advantages, such as; cost effectiveness in reducing the concentration of COD, BOD, Phosphate, and Nitrogen, compared to activated sludge systems [8] and aquatic plants [9]. Because of the lipid content in microalgae, they can float on the surface of the water (phyto-plankton). The survival of microalgae in various environmental conditions from waters to terrestrial habitats 1000 years ago has made it the oldest microorganism that lives on Earth [10]. Microalgae are cultivated in various forms of containers with various configurations. Microalgae can be cultivated in open pond systems and in closed photo-bioreactor systems under controlled environments [11], but during aquaculture operations, other microorganisms can dominate this system [12].

The use of microalgae in wastewater treatment processes provides several advantages over traditional treatment (activated sludge system), including in terms of effectiveness in reducing the concentration of COD, BOD, Phosphate, and Total Nitrogen, as well as removing compounds pathogen. In principle, the growth of photosynthetic microalgae organisms requires a supply of carbon dioxide $\left(\mathrm{CO}_{2}\right)$ as the main source of carbon, lighting of sunlight, and nutrients to produce biomass. In this study, we reported the effectiveness of organic compounds reduction in POME using locally isolated microalgae.

\section{Methodology}

\subsection{Material}

The experimental equipment's used in this study were glass reactors assembled in laboratory, spectrophotometer (UV-Vis Shimadzu 1700), Trinocular Microscope (62271-99 Zeiss Primo Star), Oven Dryer (ISUZU DSL-1000), Shaker (SLM-OS-250-Digital), Buchner Funnel (Pyrex), digital balance (ACIS, BC-500), Atman Water Pump AT-102, Lux Meter (Lutron), Low Speed Centrifuge (LC-05A), and Desiccator (Pyrex). Supporting tools are also used to conduct the research such as 32 Watt Fluorescent Lamps (Philip), Erlenmeyer $250 \mathrm{~mL}$ (Pyrex), thermometer (Yenaco), pH meter (Ohaus), and micropipettes (eppendorf). 


\subsection{POME and Microalgae}

POME was taken from the cooling pond of palm oil wastewater treatment of PT. Fajar Baizury \& Brothers Nagan Raya Regency, Aceh Province. Microalgae was isolated from open ponds around Banda Aceh City and was cultivated continuously in laboratory using BG-11 (Basic Guillerd-11) media. Chemicals were obtained commercially from Sigma-Aldrich LTD.

\subsection{General Procedure}

Research conducted was experimental with sample treatment (POME) as a medium for microalgae growth and its characteristics were analyzed against the parameters of $\mathrm{pH}, \mathrm{TSS}, \mathrm{COD}$, $\mathrm{BOD}, \mathrm{NH}_{4}, \mathrm{NO}_{3}$, and Phosphate which carried out using the standard method [13] before being inoculated with isolates and after reaching the growth phase stationary. The research was carried out at a laboratory scale by cultivating locally isolated microalgae in POME using a 3 (three) liter vessel with continuous lighting and aeration intensity. Furthermore, inoculum with a concentration of $20 \%$ was cultivated into POME media with variations concentration of $L \mathrm{P}_{100}$ (without dilution), $L \mathrm{P}_{75}$ (25\% dilution), and $\mathrm{LP}_{50}$ (50\% dilution) using aeration and continuous lighting for 15 days in vessels with a lighting intensity of 1300 lux. Cultivation of locally isolated microalgae occurred at room temperature with continuous lighting and aeration cycles for 24 hours, and every day OD samples were measured using a spectrophotometer with a wavelength of $624 \mathrm{~nm}$ to determine the growth of microalgae biomass. At the end of cultivation, media was separated by a centrifuge at a speed of $3000 \mathrm{rpm}$ for 30 minutes to obtain biomass, while the POME media was analyzed for its characteristics.

\section{Results}

\subsection{Locally Isolated Microalgae}

Microalgae was isolated from open ponds around Banda Aceh City and cultivated continuously in a bioreactor using BG-11 (Basic Guillerd-11) media. The isolates obtained were round in size with green physical pigmented characteristics and cellulose as cell wall forming as shown in Figure 1.
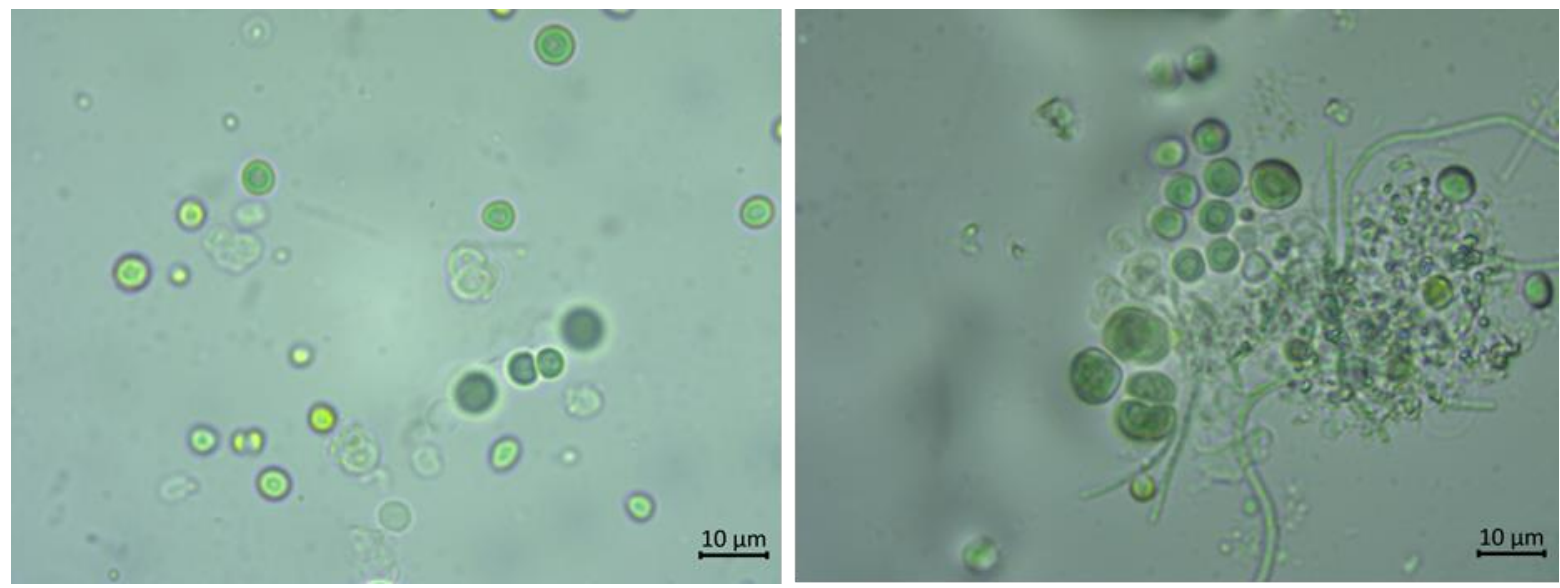

Fig. 1. Locally isolated microalgae applied to this study (on 400 magnification POME media)

Based on its characteristics, these green microalgae classified to the Chlorophyta division and class of Chlorophyceae. Green microalgae belong to a group of microalgae that have higher plant properties which are prokaryotic organisms that have special cell structures, chloroplasts, DNA in a 
nucleus, and some types have flagella. Most of the cell walls are cellulose, although some do not have cell walls. The microalgae has chlorophyll and some carotenoids which are usually green grass. When the cultivation conditions become solid and the supply of light is limited, the cell will produce more chlorophyll and become dark green. Locally isolated microalgae which were applied in this study serves to reduce the organic content of POME to be safe with the environment. In addition, this POME contains high BOD and COD values which cause contamination. Some microalgae can use autotrophic or heterotrophic carbon, such as Chlorella protothecoides which influenced by culture conditions. Furthermore, under environmental flux, microalgae can shift this mechanism, mainly due to carbon and light flux [14].

\subsection{Characteristics of POME}

POME was obtained from condensation process at the clarification station and hydro-cyclone (before entering into the Cooling Pond) in palm oil mill. These wastewater has a brownish color and a fairly high temperature of $65^{\circ} \mathrm{C}$. The $\mathrm{pH}$ of POME was measured shortly after sampling, followed by analysis of concentrations of $C O D, B O D$, suspended solids (TSS), fatty oils and analysis of the nutrient content of Ammonium $\left(\mathrm{NH}_{4}\right)$, Nitrate $\left(\mathrm{NO}_{3}-\mathrm{N}\right)$, Phosphate $\left(\mathrm{PO}_{4}\right)$. Table 1 shows the average POME content from various palm oil processing. Analysis results showed that the POME used in this study contained organic substances with a pH of 4.07, COD concentration of $60395.52 \mathrm{mg} / \mathrm{L}, \mathrm{BOD}$ concentration of $26818.30 \mathrm{mg} / \mathrm{L}$, suspended solids (TSS) concentration of $47375 \mathrm{mg} / \mathrm{L}$, fatty oil concentration of $1854.7 \mathrm{mg} / \mathrm{L}$, Ammonium $\left(\mathrm{NH}_{4}\right)$ concentration of $506.97 \mathrm{mg} / \mathrm{L}$, Nitrate $\left(\mathrm{NO}_{3}-\mathrm{N}\right)$ concentration of $190 \mathrm{mg} / \mathrm{L}$ and Phosphate $\left(\mathrm{PO}_{4}\right)$ concentration of $310 \mathrm{mg} / \mathrm{L}$. High organic substances contained in POME caused odors due to high concentrations of ammonia, which can reduce the quality of environment [15].

Table 1

Comparison of POME characteristics from various sources

\begin{tabular}{lllllll}
\hline $\mathrm{pH}$ & $\begin{array}{l}\text { BOD } \\
(\mathrm{mg} / \mathrm{L})\end{array}$ & $\begin{array}{l}\text { COD } \\
(\mathrm{mg} / \mathrm{L})\end{array}$ & $\begin{array}{l}\text { Fatty Oils } \\
(\mathrm{mg} / \mathrm{L})\end{array}$ & $\begin{array}{l}\text { TSS } \\
(\mathrm{mg} / \mathrm{L})\end{array}$ & $\begin{array}{l}\text { N-Total } \\
(\mathrm{mg} / \mathrm{L})\end{array}$ & Ref. \\
\hline 4.7 & 25,000 & 50,000 & 4,000 & 18,000 & 750 & {$[15]$} \\
$3.5-4.2$ & $10,000-44,000$ & $16,000-100,000$ & - & $5,000-54,000$ & - & {$[16]$} \\
$4.15-4.45$ & $21,500-28,500$ & $45,500-65,000$ & $1,077-7,582$ & $15,600-23,500$ & $300-410$ & {$[17]$} \\
5.6 & - & 46,000 & - & 42,800 & - & {$[18]$} \\
$3.8-4.5$ & 25,000 & 53,630 & - & 43,645 & 770 & {$[19]$} \\
4.07 & 26,818 & 60,396 & 1855 & 47,375 & 700 & this study \\
\hline
\end{tabular}

Analysis results of the POME characteristics showed that the content of suspended and dissolved solids was found with very high concentrations of organic substances, such as cellulose, proteins, fats so that if they are discharged directly without being processed it will become difficult to decompose and can pollute the environment. The results of this POME characteristic indicated that the content of suspended and dissolved solids was found with very high concentrations of organic substances because they contained such as cellulose, proteins, fats, and other components which if disposed of directly without treatment it will be difficult to decompose and will pollute the environment. Based on this result, an effective and efficient treatment process for POME waste is needed to be safely disposed of to the environment. Some researchers have also analyzed the contents of POME from various types of the palm oil industry. Table 1 emphasizes the characteristics of POME reported by several researchers. High concentrations of suspended solids and fatty oils could be a source of 
organic compounds in POME. The POME concentration used in this study was still in the range of POME concentrations reported by several previous researchers.

\subsection{Effect of POME Concentration on the Biomass Growth}

The effect of POME concentration on microalgae growth was investigated by growing a number of microalgae in various concentrations of POME media (without dilution, $\mathrm{LP}_{100} ; 25 \%$ dilution, $\mathrm{LP}_{75}$; and $50 \%$ dilution, $\mathrm{LP}_{50}$ ). This cultivation was carried out by culturing a locally isolated microalgae inoculum with a concentration of $20 \%\left(V_{\text {innoculum }} / V_{\text {media }}\right)$ into POME media under 1300 lux lighting intensity conditions with a continuous 24 -hour lighting and aeration cycle. Liquid samples were taken daily for 15 days to measure their absorbance using a spectrophotometer (UV-Vis, Shimadzu 1700) and analyzed using a calibration curve to determine the biomass content of locally isolated microalgae (g-DW/L) and the results are shown in Figure 2.

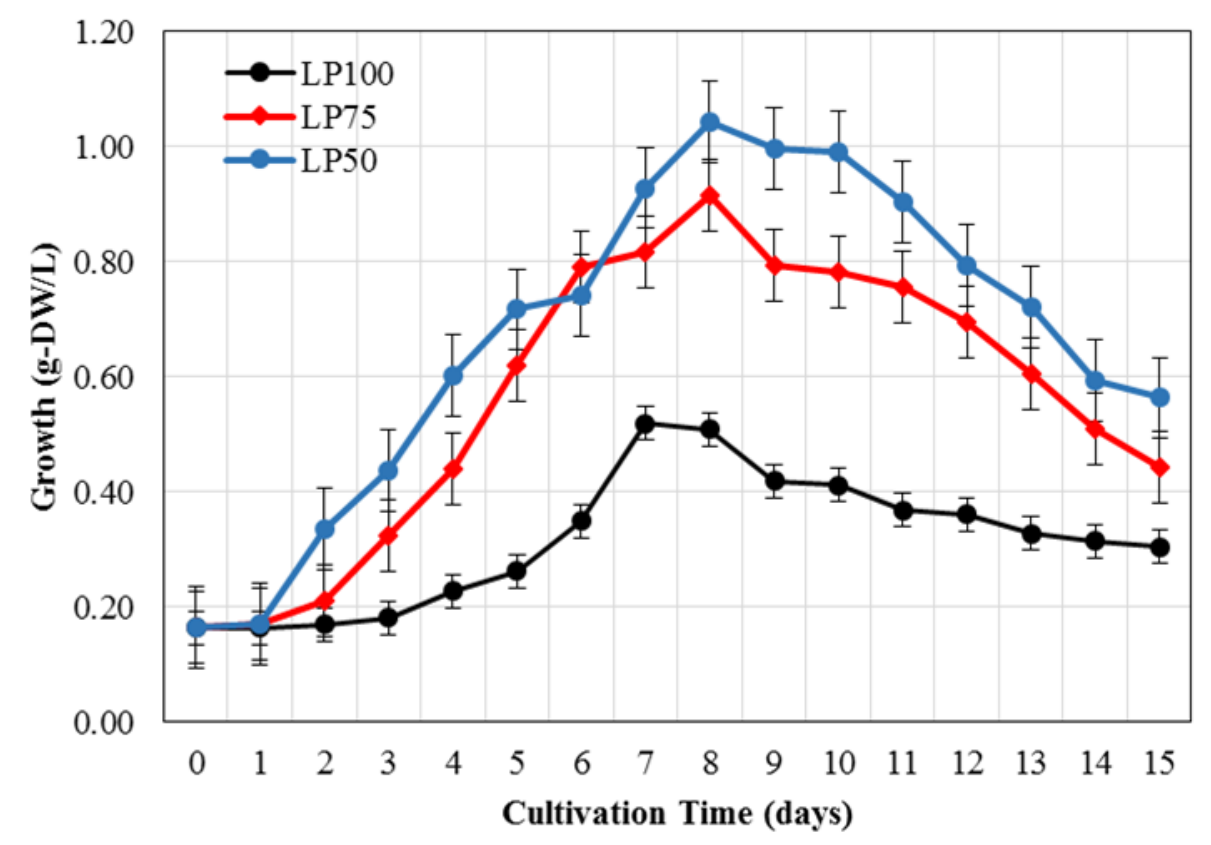

Fig. 2. Effect of media concentration on biomass growth (Condition: Inoculum concentration $20 \%$ under 1300 lux lighting intensity conditions with a continuous 24-hour lighting and aeration cycle)

Results showed that the growth of locally isolated microalgae was strongly influenced by the POME media concentration, where growth of microalgae at the concentration of $L P_{75}$ and $L_{50}$ were different from the growth at a concentration of POME LP 100 (without dilution). Growth of microalgae in $L P_{50}$ was better than in $L P_{75}$ and POME $L P_{100}$. These results indicated that the growth of microalgae was inhibited on concentrated media $\left(\mathrm{LP}_{100}\right)$. The high concentration of POME which contains high organic substances makes microalgae difficult to adapt. With a dilution of up to $50 \%\left(\mathrm{LP}_{50}\right)$, number of microalgae cells has doubled from those without dilution, and cells grew faster to adapt to their environment and increase the amount of biomass. Figure 2 shows that the growth of logarithmic phase started on day 4 to day 8 , while the stationary phase occurred from day 8 to day 9 and on the following day the growth of microalgae continues to decline until the 15th day. Concentration of organic substances in the growing media was very high, causing microalgae need a long time to adapt 
to reach the logarithmic phase in a very concentrated media. Results showed that highest microalgae growth was found in the concentration of POME LP 50 on day 8 growth which reached $1.04 \mathrm{~g}-\mathrm{DW} / \mathrm{L}$.

\subsection{Organic Substances Reduction in POME after Exposure to Locally Isolated Microalgae}

Media that have higher nutrients will inhibit the growth of microalgae because they require more time to adapt [20]. POME with certain nutrient concentrations could be a potential growth medium as an alternative medium for microalgae growth [7]. Industrial and agricultural wastewater has been evaluated as an alternative nutrient-rich culture medium for the cultivation of microalgae. Alternative culture media that have been evaluated for the cultivation of microalgae include industrial wastewater such as POME which contains residues rich in nutrients for the growth of aquaculture biomass [21, 22].

Figure 3 and Figure 4 show that POME with a high organic substance begins to degrade well by microalgae after 1-day cultivation followed by microalgae growth. In this adaptation phase, microalgae could survive, followed by the logarithmic phase until the 9th day of cultivation, nutrients as a food source in POME continue to decrease. Reduction of nutrients was in line with the decrease in organic substances in POME. Results showed that the presence of microalgae in POME at the concentrations of $\mathrm{LP}_{75}$ for 12 days decreased organic substances and nutrients reaching $80.74 \%$ 99.70\%. Some parameters that were reduced include BOD (99.35\%), COD (89.57\%), TSS (89.68\%), Phosphate (97.70\%), Ammonium (95.08\%), Fatty Oil (99.70\%), and Nitrates (80.74\%).

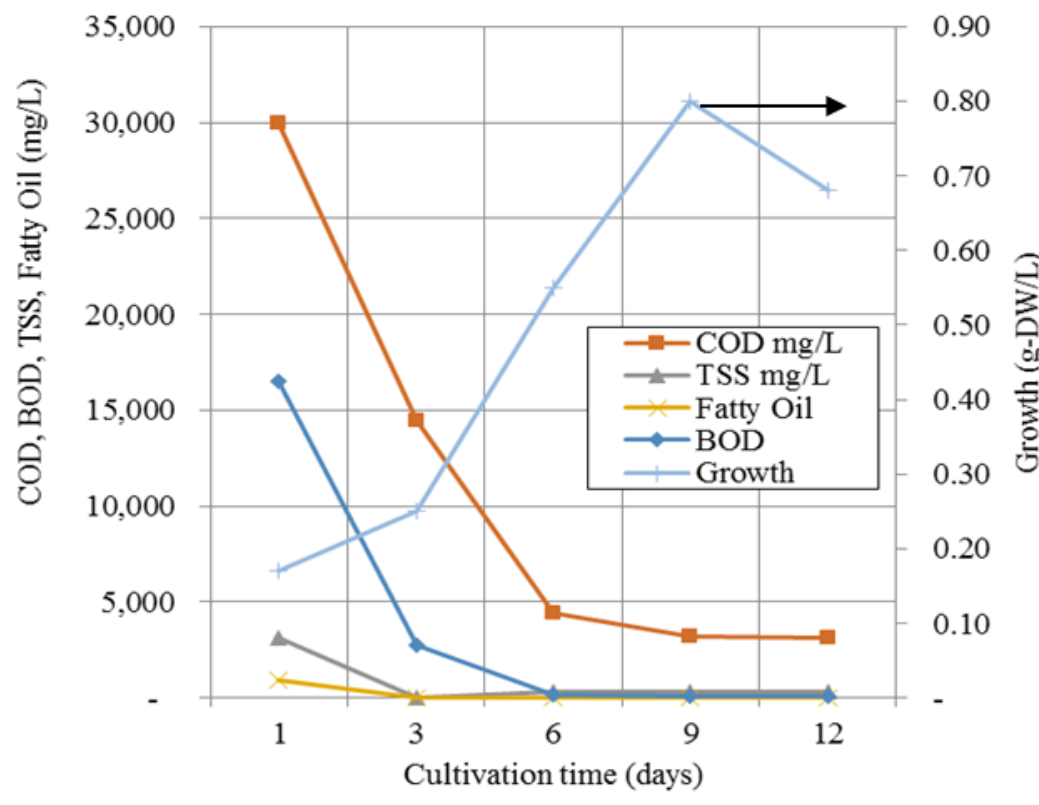

Fig. 3. Effect of cultivation of locally isolated microalgae in POME on the reduction of COD, BOD, TSS, and fatty oil 


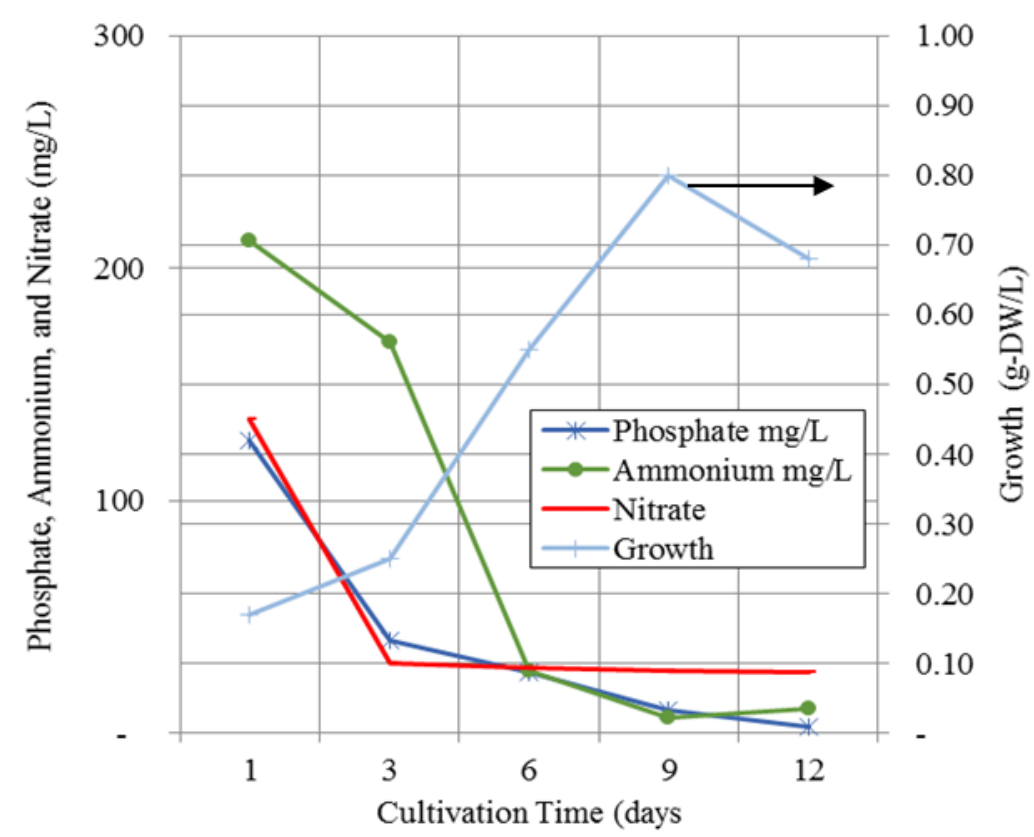

Fig. 4. Effect of cultivation of locally isolated microalgae in POME on the reduction of phosphate, ammonium, and nitrate

\section{Conclusions}

Research showed that locally isolated microalgae grew well in POME at LP75 and $\mathrm{LP}_{50}$ concentrations with the inoculum concentration of $20 \%$ under 1300 lux lighting intensity conditions with a continuous 24-hour lighting and aeration cycle that produces biomass content of 0.92 and 1.08 g-DW/L, respectively. The presence of microalgae in POME at concentration of $\mathrm{LP}_{75}$ for 12 days reduced organic substances and nutrients reaching $80.74 \%-99.70 \%$. Parameters that were reduced include BOD (99.35\%), COD (89.57\%), TSS (89.68\%), Phosphate (97.70\%), Ammonium (95.08\%), Fatty Oil $(99.70 \%)$, and Nitrates (80.74\%). This research concluded that locally isolated microalgae have the ability to treat POME safely for the environment and as a growing medium for microalgae followed by a decrease in organic substances.

\section{References}

[1] Pye, Oliver. "Commodifying sustainability: Development, nature and politics in the palm oil industry." World Development 121 (2019): 218-228. https://doi.org/10.1016/j.worlddev.2018.02.014

[2] Laurance, William F., Lian P. Koh, Rhett Butler, Navjot S. Sodhi, Corey JA Bradshaw, J. David Neidel, Hazel Consunji, and Javier Mateo Vega. "Improving the performance of the roundtable on sustainable palm oil for nature conservation." Conservation Biology 24, no. 2 (2010): 377-381. https://doi.org/10.1111/j.1523-1739.2010.01448.x

[3] Kadandale, Sowmya, Robert Marten, and Richard Smith. "The palm oil industry and noncommunicable diseases." Bulletin of the World Health Organization 97, no. 2 (2019): 118. https://doi.org/10.2471/BLT.18.220434

[4] Bakar, MA Abu, W. J. Yahya, and Z. Mohamad. "Pollution Reduction Technology in Palm Oil Mill through Effluent Treatment and Management." Journal of Advanced Vehicle System 1, no. 1 (2016): 8-15.

[5] Islam MS Tajul, Md Zahangir Alam, Abdullah Al-Mamun, Amal A. Elgharbawy, and Fatimah A. Riyadi. "Development of enzymatic pretreatment of palm oil mill effluent for monomers towards biogas production." Journal of Advanced Research in Materials Science 38, no. 1 (2017): 39-44.

[6] Ahmad, Ashfaq, Azizul Buang, and A. H. Bhat. "Renewable and sustainable bioenergy production from microalgal co-cultivation with palm oil mill effluent (POME): a review." Renewable and Sustainable Energy Reviews 65 (2016): 214-234. https://doi.org/10.1016/i.rser.2016.06.084

[7] Habib, M. A. B., F. M. Yusoff, S. M. Phang, and S. Mohamed. "Growth and Nutritional Values of Moina micrura fed on Chlorella vulgaris grown in digested palm oil mill effluent." Asian Fisheries Science 16, no. 1/2 (2003): 107-120. 
[8] Woertz, lan C. "Lipid productivity of algae grown on dairy wastewater as a possible feedstock for biodiesel." Master's Theses and Project Reports (2008): 183.

[9] Syafrizal, Suhendrayatna, Zaki, Muhammad, Elvitriana. "Degradation of Nitrate, Ammonium and Phosphate in Domestic Wastewater by Aquatic Plants, Actinoscirpus grossus in Floating Treatment Wetland System (FTWs)." In Materials Science and Engineering Conference Series, vol. 796, no. 1, p. 012058.2020. https://doi.org/10.1088/1757-899X/796/1/012058

[10] Mata, Teresa M., Antonio A. Martins, and Nidia S. Caetano. "Microalgae for biodiesel production and other applications: a review." Renewable and sustainable energy reviews 14, no. 1 (2010): $217-232$. https://doi.org/10.1016/i.rser.2009.07.020

[11] Sullivan Graham, E. J., C. A. Dean, T. M. Yoshida, S. N. Twary, M. Teshima, M. A. Alvarez, T. Zidenga et al. "Oil and gas produced water as a growth medium for microalgae cultivation: a review and feasibility analysis. Algal Res 24 : 492-504." (2017). https://doi.org/10.1016/i.algal.2017.01.009

[12] Schenk, Peer M., Skye R. Thomas-Hall, E. Marx Stephens, Mussgnug U C, and Posten JH. "C., Kruse, O. \& Hankamer, B. (2008). Second Generation Biofuels: High-Efficiency Microalgae for Biodiesel Production." Bioenerg. Res 1, no. 1: 20-43. https://doi.org/10.1007/s12155-008-9008-8

[13] Baird, Rodger B., Andrew D. Eaton, Eugene W. Rice, and Laura Bridgewater, eds. Standard methods for the examination of water and wastewater. Washington, DC: American Public Health Association, 2017.

[14] Chen, Chun-Yen, Kuei-Ling Yeh, Rifka Aisyah, Duu-Jong Lee, and Jo-Shu Chang. "Cultivation, photobioreactor design and harvesting of microalgae for biodiesel production: a critical review." Bioresource technology 102, no. 1 (2011): 71-81. https://doi.org/10.1016/i.biortech.2010.06.159

[15] Ahmad, Abdul Latif, Suzylawati Ismail, and Subhash Bhatia. "Water recycling from palm oil mill effluent (POME) using membrane technology." Desalination 157, no. 1-3 (2003): 87-95. https://doi.org/10.1016/S00119164(03)00387-4

[16] Zhang, Yejian, Y. A. N. Li, Q. I. A. O. Xiangli, C. H. I. Lina, N. I. U. Xiangjun, M. E. I. Zhijian, and ZhenJia Zhang. "Integration of biological method and membrane technology in treating palm oil mill effluent." Journal of Environmental Sciences 20, no. 5 (2008): 558-564. https://doi.org/10.1016/S1001-0742(08)62094-X

[17] Wong, Yee Shian, Mohd Omar AB Kadir, and Tjoon Tow Teng. "Biological kinetics evaluation of anaerobic stabilization pond treatment of palm oil mill effluent." Bioresource technology 100, no. 21 (2009): 4969-4975. https://doi.org/10.1016/i.biortech.2009.04.074

[18] Damayanti, A., Z. Ujang, M. R. Salim, Gustaf Olsson, and A. Z. Sulaiman. "Respirometric analysis of activated sludge models from palm oil mill effluent." Bioresource technology 101, no. 1 (2010): $144-149$. https://doi.org/10.1016/j.biortech.2009.08.034

[19] Abdullah, Ahmad Zuhairi, Mohamad Hakimi Ibrahim, and Mohd Omar Ab Kadir. "Treatment of Palm Oil Mill Effluent (POME) Supernatants Using Aerobic Attached-Growth System: Trickling Filter as a Case Study." Jurnal Teknologi 40, no. 1 (2004): 77-90. https://doi.org/10.11113/jt.v40.424

[20] Hirayama, Kazutsugu. "Effects of bacterial coexistence on the growth of a marine diatom Chaetoceros gracilis." Fisheries science 62, no. 1 (1996): 40-43. https://doi.org/10.2331/fishsci.62.40

[21] Bertoldi, Fabiano Cleber, Ernani Sant'Anna, Maurício Villela da Costa Braga, and Jorge Luiz Barcelos Oliveira. "Lipids, fatty acids composition and carotenoids of Chlorella vulgaris cultivated in hydroponic wastewater." Grasas $y$ aceites 57, no. 3 (2006): 270-274. https://doi.org/10.3989/gya.2006.v57.i3.48

[22] Bertoldi, F. C., E. Sant'Anna, and J. L. Barcelos-Oliveira. "Chlorella vulgaris cultivated in hydroponic wastewater." In International Symposium on Soilless Culture and Hydroponics 843, pp. 203-210. 2008. https://doi.org/10.17660/ActaHortic.2009.843.26 